\title{
Recovery dynamics and invasibility of herbaceous plant communities after exposure to fifty-year climate extremes in different seasons
}

\section{F. E. Dreesen, H. J. De Boeck, I. A. Janssens, and I. Nijs}

Research Group of Plant and Vegetation Ecology, Department of Biology, University of Antwerp, Wilrijk, Belgium

Received: 8 July 2013 - Accepted: 11 September 2013 - Published: 11 October 2013 Correspondence to: F. E. Dreesen (freja.dreesen@ua.ac.be)

Published by Copernicus Publications on behalf of the European Geosciences Union.

Recovery and invasibility dynamics after seasonal $50-\mathrm{yr}$

climate extremes

F. E. Dreesen et al.

\section{Title Page}

Abstract Introduction

Conclusions

References

Tables Figures

14 $\rightarrow$

4

Back

Close

Full Screen / Esc

Printer-friendly Version

Interactive Discussion 


\section{Abstract}

Disturbance events such as climatic extremes may enhance the invasibility of plant communities, through the creation of gaps and the associated local increase in available resources. In this study, experimental herbaceous communities consisting of three 5 species were subjected to $50 \mathrm{yr}$ extreme drought and/or heat events, in spring, summer or autumn. In the year of the induced extremes, species mortality and end-of-season biomass were examined. In two subsequent years without further disturbances, establishment of new species was recorded.

The drought and drought + heat extremes in summer and autumn induced greater plant mortality compared with the heat extremes in those seasons and compared with all extremes applied in spring, in all three originally planted species. Recovery in terms of biomass towards the end of the growing season, however, was species-specific. The dominant species, the nitrogen fixer Trifolium repens, recovered poorly from the drought and drought + heat extremes which governed the community response. Community biomass, which was heavily affected by the drought and especially by the drought + heat events in summer and autumn, reached control values already one year later. Invasibility was increased in the communities that underwent the drought + heat extremes in the first year following the extreme events, but no longer in the second year. During the two years of invasion, the community composition changed, but independently of the type and impact of the extreme event.

In short, the extreme climate events greatly affected the survival and productivity of the species, modified the species composition and dominance patterns, and increased the invasibility of our plant communities. However, none of these community properties seemed to be affected in the long term, as the induced responses faded out after one or two years.
BGD

10, 15851-15877, 2013

Recovery and

invasibility dynamics

after seasonal $50-y r$

climate extremes

F. E. Dreesen et al.

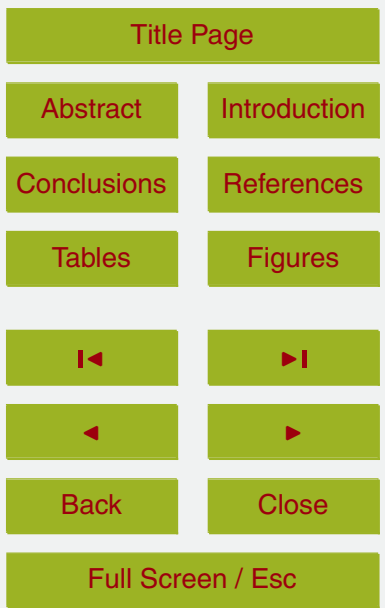

Printer-friendly Version

Interactive Discussion 


\section{Introduction}

Extreme climatic events have become a key issue in climate change research, in view of their increasing frequency and intensity and their potential disastrous impact on ecosystems (IPCC, 2012). In plant communities, especially intense drought and heat events can cause major disturbance, including loss of productivity (Ciais et al., 2005; Hanson and Weltzin, 2000; De Boeck et al., 2011; Peñuelas et al., 2007) and enhanced die-off (Breshears et al., 2005; Kreyling et al., 2008b). This leads to decreased carbon uptake from the atmosphere, which can be diminished for multiple years due to lagged responses such as mortality in the years following the extreme event, slow recovery or increased sensitivity to pests or future event (Arnone et al., 2008; Bréda et al., 2006; Reichstein et al., 2013). This might even turn $\mathrm{CO}_{2}$ sinks in sources, creating a positive feedback on climate warming (Reichstein et al., 2013). An additional effect of extreme events is that they may render communities more sensitive to invasion by new species since disturbance, by creating gaps in the original community, is a major driver persistence of plant communities besides the direct effect of the events themselves.

According to the fluctuating resource availability theory (Davis et al., 2000), a community becomes more susceptible to invasion when the amount of unused resources is increased (provided this coincides with the arrival of invasive seeds). This occurs when resource uptake by the resident community is diminished (e.g. following plant mortality) or when an increase in resources exceeds the sequestration rate of the resident plants (e.g. following improved water supply or eutrophication) (Davis et al., 2000). Several studies have indeed reported enhanced invasibility after various types of disturbance events, including droughts (Belote et al., 2008; Burke and Grime, 1996; Davis and Pelsor, 2001; Jiménez et al., 2011; Kreyling et al., 2008a; Renne et al., 2006). However, invasibility could also be reduced by disturbance when the events are recurrent and too severe, creating suboptimal conditions. Only few species will then be sufficiently disturbance-tolerant to be able to colonize and establish in such environ-
BGD

10, 15851-15877, 2013

Recovery and

invasibility dynamics

after seasonal 50-yr

climate extremes

F. E. Dreesen et al.

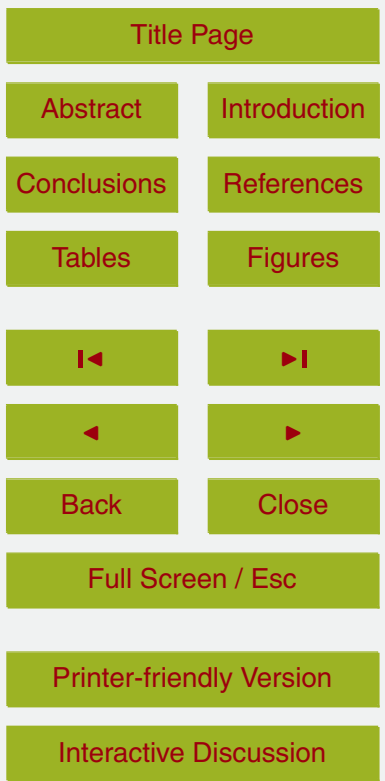


ments (Davis et al., 2005; Kreyling et al., 2008a). The theory of Davis et al. (2000) furthermore states that invasibility is not necessarily related to other factors such as the species richness or species diversity of the resident community (the diversity - invasibility controversy, e.g. Dukes, 2001; Frankow-Lindberg, 2012; Naeem et al., 2000; 5 van Ruijven et al., 2003). Nonetheless, disturbance can influence the diversity of communities through mortality, and invasibility can in turn determine diversity through newly incoming species, suggesting that diversity, disturbance (i.e. changes in available resources) and invasibility all co-vary with each other (Belote et al., 2008; Clark and Johnston, 2011; Davis et al., 2005; Renne et al., 2006; Shea and Chesson, 2002).

The species that enter the community after an extreme climatic event can be expected to have specific characteristics that determine their invasion success in such a disturbed environment, since local abiotic factors or competition would filter out unsuitable species (MacDougall et al., 2008). Jiménez et al. (2011), for example, observed increased invasion by exotic species after extreme drought, but an increased abundance of native annuals after rainfall events. Also Kreyling et al. (2008a) reported greater invasion of species with a specific affinity to either extreme drought or rainfall, after an occurrence of those conditions. Furthermore, resident species might influence the invasion success of specific invaders. Fargione et al. (2003) demonstrated that resident species can inhibit the invasion of other species from the same functional group, which can be explained by niche differentiation between functional groups. Invaders would thus perform better when their functional traits and pattern of resource use differ from that of resident species (Tilman, 2004). In addition, newly incoming species can influence carbon and nutrient cycles of an existing community (through species-specific impacts on productivity, above and belowground carbon and nitrogen storage, rooting depth ...). For example, grasses invading a semiarid shrubland have been found to increase carbon and nitrogen storage while the opposite event decreased carbon storage (Jackson et al., 2002; Wolkovich et al., 2010). Meta-analysis of plant invasion studies revealed that invading woody and nitrogen-fixing species usually had a greater impact on carbon and nitrogen cycles than those by herbaceous and non-nitrogen fixing

BGD

10, 15851-15877, 2013

Recovery and

invasibility dynamics after seasonal 50-yr climate extremes

F. E. Dreesen et al.

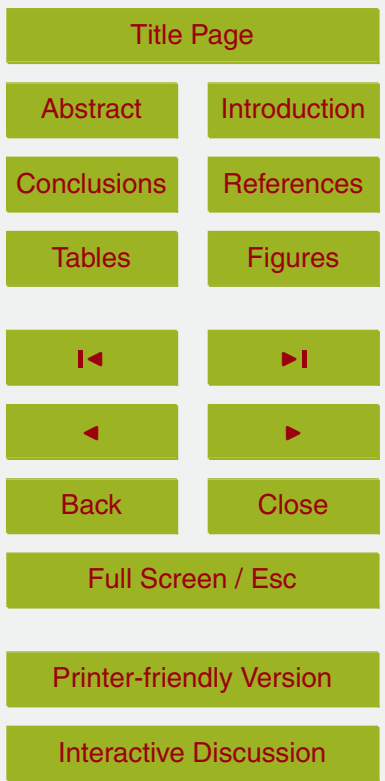


species (Liao et al., 2008). Knowledge on how extreme events would affect community composition after an extreme event might therefore be important.

In this study, we subjected constructed plant communities consisting of three common herbaceous species to experimentally induced extreme drought and/or heat events, in spring, summer or autumn. Following the year during which the extremes were imposed, other species were allowed to invade the plant communities. Community productivity responses during the year of the events have been reported in De Boeck et al. (2011). Here we investigate the species-specific responses in the year of exposure and during two years of subsequent recovery. We expect differences in mortality and productivity between the various events to be reflected in the species invading the communities. Our principle objective is thus to determine how community composition will evolve depending on disturbance history.

\section{Material and methods}

\subsection{Study site, plant material and treatments}

15 This study was conducted from April 2009 until October 2011 at an experimental field site on the Drie Eiken Campus of the University of Antwerp (Belgium, $51^{\circ} 09^{\prime} \mathrm{N}$, $4^{\circ} 24^{\prime} \mathrm{E}$ ). Mean annual air temperature at this location with a temperate maritime climate is $9.6^{\circ} \mathrm{C}$ and mean annual precipitation is $780 \mathrm{~mm}$, equally distributed over the year.

In 2009, experimental plant communities were subjected to extreme climatic events imposed in different seasons. The communities were grown under control conditions without extremes (C) or exposed to a single extreme event - either drought (D), heat $(\mathrm{H})$ or the combination of drought and heat $(\mathrm{DH})$ - in either spring, summer or autumn. The communities (216 in total), consisted of three common herbaceous species (Plantago lanceolata L., Rumex acetosella L. and Trifolium repens L.) and were established in containers $(20 \mathrm{~cm}$ diameter, $40 \mathrm{~cm}$ depth). Each of the communities contained 10
BGD

$10,15851-15877,2013$

Recovery and

invasibility dynamics

after seasonal 50-yr

climate extremes

F. E. Dreesen et al.

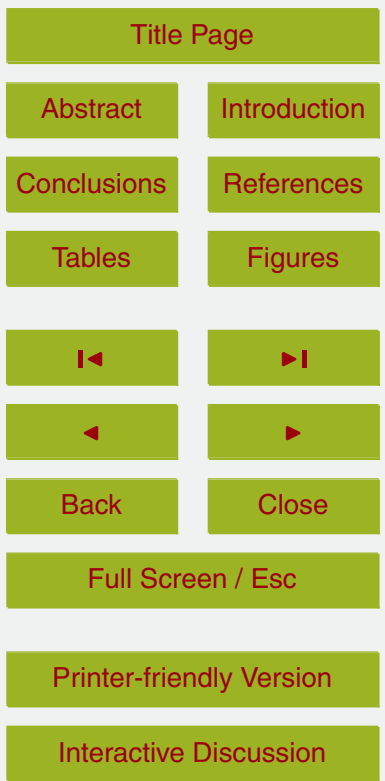


plants (three individuals of each species; the tenth individual was altered every three communities to ensure equal representation of all three species across the $18 \mathrm{com}$ munities per treatment). The plants were arranged in a hexagonal design with only interspecific neighbours. We chose experimental plant communities over natural com5 munities as differences between replicates (such as soil structure, species interactions and nutrient availability) are minimized, increasing comparability between treatments. The soil used in the containers was sandy (96\% sand, $1.5 \%$ silt and $2.5 \%$ clay; $\mathrm{pH}$ $7.6 ; 1.3 \%$ C, $19 \mathrm{mg}$ nitrate-N, $1.1 \mathrm{mg}$ ammonium-N and $550 \mathrm{mg}$ Kjeldahl-N per kg dry soil). The water content was $0.15 \mathrm{~m}^{3} \mathrm{~m}^{-3}$ at field capacity ( $\mathrm{pF} 2.5$ ) and $0.037 \mathrm{~m}^{3} \mathrm{~m}^{-3}$ at 10 wilting point ( $\mathrm{pF} 4.2$ ), determined by a soil laboratory (Belgische Bodemkundige Dienst, Leuven, Belgium).

The plant containers were placed in six watertight boxes $(135 \times 135 \mathrm{~cm})$ which were embedded in the soil. Each of the boxes was separated in two halves. Each half represented a separate treatment (either $\mathrm{C}, \mathrm{D}, \mathrm{H}$ or $\mathrm{DH}$ ) and contained 18 replicate plant communities. A fixed water table was manually maintained in the watertight boxes at $34 \mathrm{~cm}$ from the surface, to provide sufficient water. The plant containers had a perforated lid at the bottom to allow water drainage and inflow. In each box, the water table was sustained in one half $(\mathrm{C}$ and $\mathrm{H}$ treatments), while in the other half drought was induced at the appropriate time by removal of the water table ( $\mathrm{D}$ and $\mathrm{DH}$ treatments). Above three of the six boxes (which contained both the $\mathrm{H}$ and $\mathrm{DH}$ treatments), a set of six $1500 \mathrm{~W}$ infrared lamps were suspended at a height of $120 \mathrm{~cm}$. Above the other three boxes (containing the $C$ and $D$ treatments), dummy lamps were placed. Three half boxes were provided for the control treatment (thus 18 replicate communities per extreme event treatment but 54 control communities). The communities were relocated twice between the boxes (in June and August), to avoid location-specific effects. Permanent rain shelters $(3.60 \mathrm{~m}$ by $3.60 \mathrm{~m})$ with angular roofs with a height of $200-240 \mathrm{~cm}$, consisting of transparent polycarbonate, prevented precipitation from reaching the communities. Because of their height, full air exchange with the surround-
BGD

$10,15851-15877,2013$

Recovery and

invasibility dynamics after seasonal $50-y r$ climate extremes

F. E. Dreesen et al.

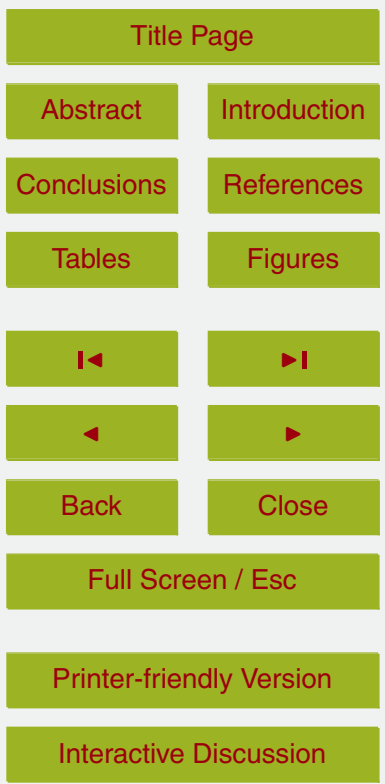


ings was ensured, hence the build-up of heat $\left(+0.2^{\circ} \mathrm{C}\right)$ and relative humidity $(+3 \%$ on average) underneath the shelters were modest.

The intensity of the extremes was chosen to mimic events currently occurring once every $50 \mathrm{yr}$. The length of the drought extremes was determined by interpolation of 5 return time data, using the long-term database of the Royal Meteorological Institute of Belgium (records from 1880-2003), as the number of consecutive days with daily precipitation less than $1 \mathrm{~mm}$. Drought lengths were analyzed for every month separately (but with overlap allowed between the preceding and following month). This analysis yielded 26, 25 and 31 days of withholding water for the spring (17 April-13 10 May), summer (6-31 July) and autumn (8 September-9 October) extremes, respectively. The heat extremes always lasted 10 days (a realistic length for the region, De Boeck et al., 2010) and were applied at the end of the drought period. Maximum daily air temperatures during the heat extremes were calculated similarly to the precipitation records, by interpolation of return time data. The average daily maximum air temper15 atures during the 10 day heat waves resulting from this analysis were $25.6^{\circ} \mathrm{C}, 29.8^{\circ} \mathrm{C}$ and $21.9^{\circ} \mathrm{C}$ for the spring, summer and autumn extremes, respectively (which was in all cases approximately $7^{\circ} \mathrm{C}$ above the outside maximum temperatures). The soil water content that was reached at the end of the drought + heat waves was near or below the wilting point of $0.037 \mathrm{~m}^{3} \mathrm{~m}^{-3}$ in all three seasons $\left(0.038 \mathrm{~m}^{3} \mathrm{~m}^{-3}, 0.034 \mathrm{~m}^{3} \mathrm{~m}^{-3}\right.$ and $0.036 \mathrm{~m}^{3} \mathrm{~m}^{-3}$ for the spring, summer and autumn $\mathrm{DH}$ treatments, respectively). Also the summer $D$ treatment almost reached wilting point $\left(0.038 \mathrm{~m}^{3} \mathrm{~m}^{-3}\right)$, while the spring and autumn drought evoked less dry soil conditions $\left(0.072 \mathrm{~m}^{3} \mathrm{~m}^{-3}\right.$ and $0.11 \mathrm{~m}^{3} \mathrm{~m}^{-3}$, respectively). At the end of the drought events, water was added manually to bring the soil water content back to field capacity. In the control and heat wave treatments, the soil water content was always near field capacity $\left(0.15 \mathrm{~m}^{3} \mathrm{~m}^{-3}\right)$.

After the biomass harvest in the year of the imposed extremes (October 2009, see below), 72 communities ( 6 per treatment and 18 control communities) were removed from the experimental set-up and exposed to ambient air and precipitation. From that moment on, new species were allowed to naturally invade the communities (seeds were

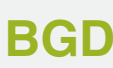

10, 15851-15877, 2013

Recovery and

invasibility dynamics

after seasonal 50-yr

climate extremes

F. E. Dreesen et al.

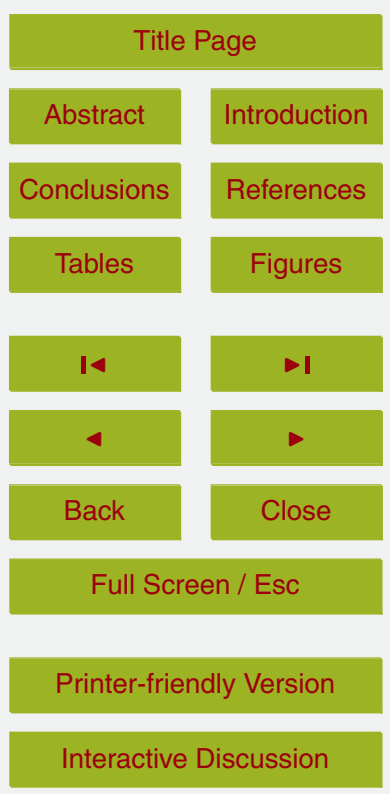

\section{7}


not added manually). Mean monthly air temperature and monthly precipitation during 2010 and 2011 are shown in Fig. 1 (data from a weather station situated $10 \mathrm{~km}$ from the experimental field site). Each year, the communities were clipped (with removal of all aboveground material above $4 \mathrm{~cm}$ ) on 19-20 June and 26-30 October, in order to 5 simulate mowing practices in extensively managed grassland. No fertilizer was added to the communities.

\subsection{Measurements}

Species apparent mortality (no visible green tissue) was recorded on the last day of the induced extreme events in 2009 (i.e. on 13 May, 31 July and 9 October) by counting 10 all living plants in 6 replicate communities per treatment. At the end of each growing season (October 2009, 2010 and 2011), the harvested aboveground biomass was separated by species and weighed after drying for $72 \mathrm{~h}$ at $70^{\circ} \mathrm{C}$.

\subsection{Data analysis}

All species recorded were classified according to their establishment strategy in the 15
CSR model: competitive species, stress-tolerant species or ruderals (Grime et al., 1988). The CSR theory gives a relative C, S and R score for each species according to their position in a virtual triangle where these three types represent the extremes. By taking into account all the species present in the communities of a given treatment, and by weighting the CSR-scores of the species with their aboveground biomass, a mean biomass-weighted score for competitiveness, stress-tolerance and ruderality per treatment was obtained.
BGD

$10,15851-15877,2013$

Recovery and

invasibility dynamics

after seasonal 50-yr

climate extremes

F. E. Dreesen et al.

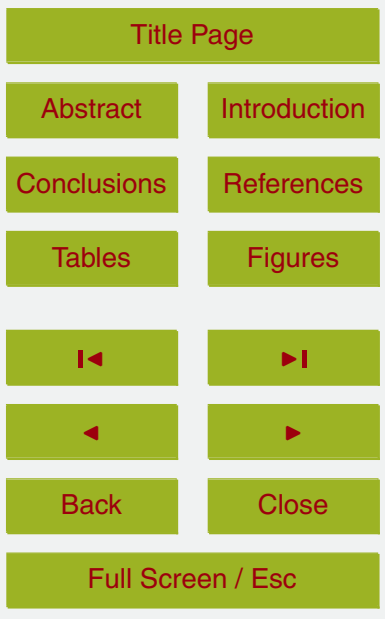

Printer-friendly Version

Interactive Discussion 
The Relative Euclidean Distance (RED) was calculated, in order to compare the species compositional dissimilarity between communities, using the formula

$\operatorname{RED}_{j k}=\sqrt{\frac{1}{n} \sum_{i=1}^{n}\left(\frac{x_{i j}}{\sum_{i=1}^{n} x_{i j}}-\frac{x_{i k}}{\sum_{i=1}^{n} x_{i k}}\right)^{2}}$

in which $\mathrm{RED}_{j k}=$ Relative Euclidian Distance between plots $j$ and $k, n=$ total number 5 of species, and $x_{i j}=$ biomass of species $i$ in plot $j$. The RED was calculated both within treatments (all two by two comparisons between the replicate communities of one treatment) and between the different treatments and the control treatment (all two by two comparisons between the replicates of one treatment and the replicates of the controls).

One-way ANOVA was used to test for differences between the extreme treatments in CSR, RED, biomass and newly established species data. Post-hoc tests to detect differences between treatments were performed with the Tukey-Kramer correction. An ANOVA model for binomially distributed data was applied to test for differences in plant mortality. This model uses a chi-square test $x^{2}$ instead of an $F$ test that is used in

(version 9.1 SAS Institute Inc., Cary, NC, USA) with a significance threshold of 0.05

\section{Results}

\subsection{Mortality and productivity during the year of the climate extremes (2009)}

Figure 2a shows the plant mortality per species on the last day of the seasonal extremes, i.e. on DOY 133, 212 and 282 for spring, summer and autumn, respectively. Among the extremes occurring in spring, only the $\mathrm{DH}$ treatment had an impact. This 15859

$10,15851-15877,2013$

Recovery and

invasibility dynamics

after seasonal $50-\mathrm{yr}$

climate extremes

F. E. Dreesen et al.

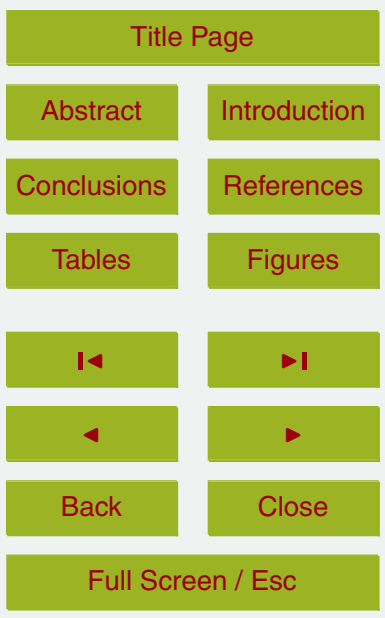

Printer-friendly Version

Interactive Discussion 
event led to substantial plant mortality in $T$. repens ( $23 \%$ mortality, $P=0.004$ ), but not in the other two species. When occurring in summer, the DH extreme affected all three species, causing more than $80 \%$ plant mortality ( $P$ values for $P$. lanceolata, $T$. repens and $R$. acetosella all below 0.001$)$. The summer $D$ extreme reduced the number of liv5 ing plants of T. repens and $R$. acetosella by $32 \%$ and $30 \%$, respectively $(P<0.001$ and $P=0.03$ ), but induced no mortality in $P$. lanceolata. In autumn, the $\mathrm{DH}$ treatment also brought significant plant mortality in all three species, ranging from $45 \%$ in $P$. lanceolata to $67 \%$ in $R$. acetosella (all $P$ values below 0.001 ), while the autumn $\mathrm{D}$ extreme had an impact only on $R$. acetosella (mortality of $20 \%, P=0.03$ ). The $\mathrm{H}$ extremes never caused loss of living plants, in any of the seasons.

By the end of the growing season, much of the observed plant mortality had been compensated by regrowth (Fig. 2b). For example, the DH spring extreme did not alter species aboveground biomass, despite the mortality in $T$. repens. Also the mortality caused by the summer $\mathrm{D}$ and $\mathrm{DH}$ extremes in $P$. lanceolata and $R$. acetosella was no longer apparent in the end-of-season biomass (Fig. 2b). T. repens, on the other hand, did not recover from the summer extremes, leaving a reduced (borderline significant) biomass after the summer $\mathrm{D}$ extreme $(-34 \% ; P=0.052)$ and nearly no biomass after the summer $\mathrm{DH}$ extreme $(P<0.0001)$. In response to the autumn $\mathrm{D}$ and $\mathrm{DH}$ extremes, T. repens likewise had much less biomass left than the controls $(-37 \%$ and $-73 \%$; $P=0.045$ and $P<0.001$, respectively). Furthermore, the autumn $\mathrm{DH}$ treatment was the only treatment from which $P$. lanceolata en $R$. acetosella could not recover, resulting in a biomass decline of $41 \%$ and $92 \%$, respectively $(P<0.001$ and $P=0.004$; note that the recovery period after the autumn extremes was shorter than those of the summer and spring extremes).
BGD

$10,15851-15877,2013$

Recovery and

invasibility dynamics

after seasonal 50-yr

climate extremes

F. E. Dreesen et al.

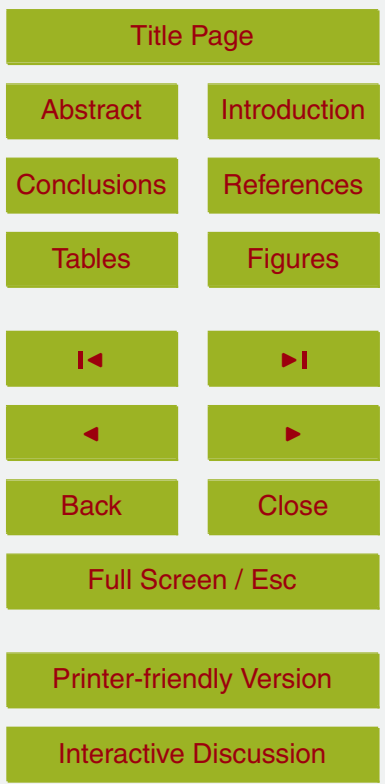




\subsection{Invasibility after extremes}

\subsubsection{Species richness}

Since the various extreme events induced mortality and lowered productivity to different degrees, we expected diverse rates of recovery and invasion patterns. One year

5 after the climate extremes (thus in 2010), more newly established species were found in the $\mathrm{DH}$ treatments (Fig. $3 \mathrm{a}, P=0.005$, the three seasonal $\mathrm{DH}$ treatments did not differ among themselves). Furthermore, a relationship had developed between the plant mortality caused by the extremes in 2009 and the number of newly established species (Fig. 3c, the mean plant mortality at community level was used, since all species had 10 the same mortality pattern; $R^{2}=0.55, P=0.02$ ). However, in 2011 , two years after the applied extremes, no differences in the number of newly established species between the treatments remained (Fig. 3b), and the relationship with mortality in 2009 no longer existed (Fig. 3c, $R^{2}=0.001$ ).

\subsubsection{Community composition}

15 Table S1 lists all the species found in the plant communities and their aboveground biomass, including the three originally planted species. More than 30 species were identified across all communities during 2010 and 2011. The list shows major variation in species composition and biomass among treatments, but also among replicates within the same treatment. For example, in one control community, Trifolium pratense was very productive. However, no other replicate among the 18 control communities included this species, creating large standard errors and within-treatment variance when pooling all replicate communities from the same treatment. More such examples associated with other species can be found in Table S1 (e.g. Betula pendula, Achillea millefolium, Cirsium arvense, Lotus coniculatus and Epilobium sp.). As a result of this variation, in 2010, all treatments had the same degree of compositional dissimilarity among their replicates (quantified through the Relative Euclidean Distance, see Ta-

Recovery and

invasibility dynamics after seasonal $50-\mathrm{yr}$ climate extremes

F. E. Dreesen et al.

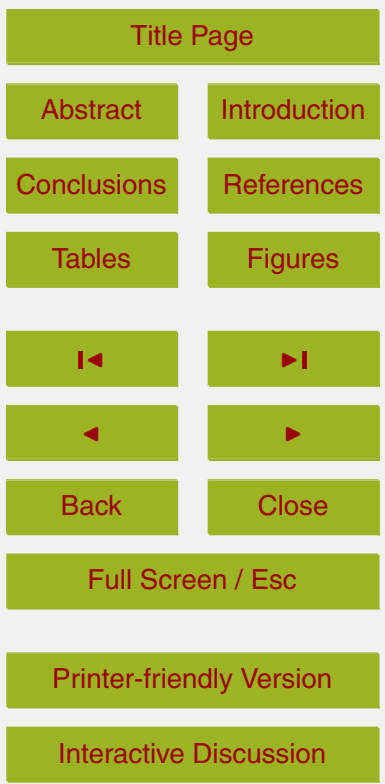


ble 1). However, when the extreme manipulation treatments were compared to the control (two by two comparison), the summer DH treatment was the only one with a significantly different composition $(P=0.03)$. This dissimilarity between the summer $\mathrm{DH}$ and the control treatment disappeared again in 2011 (Table 1). The RED value 5 within each treatment increased with time (Table 1), indicating that replicates became less similar.

The summer $\mathrm{DH}$ extreme in 2009 lowered the biomass-weighted score for community competitiveness (Fig. $4 \mathrm{a}, P<0.001$ ). The biomass-weighted score for community stress-tolerance, on the other hand, was significantly increased (only) after this treat-

ment (Fig. 4a, $P<0.001$ ). Summer exposure to $\mathrm{DH}$ thus disrupted the original balance between competitive and stress-tolerant species. One year after the induced extreme events (in 2010), the biomass-weighted score for stress-tolerance in the summer DH treatment had decreased again $(P=0.008)$ as a result of biomass restoration of competitive species (Fig. 4b). The score for biomass-weighted ruderality never changed in

response to the extremes, neither in the year of the applied extremes, nor afterwards (data not shown). Two years after the induced extreme events (in 2011), all treatments again had the same score for biomass-weighted competitiveness and stress-tolerance (Fig. 4c).

\subsubsection{Biomass}

20 The aboveground community biomass in the year in which the extremes were applied (Fig. 5a), reflected to a large extent the response of $T$. repens (see Fig. $2 \mathrm{~b}$, middle panel), with strong decreases after the summer and autumn D and DH treatments. One year later, in 2010, no biomass differences remained (Fig. 5b), not even in the communities that had experienced substantial plant mortality and biomass decrease.

25 This was also the case in 2011 (Fig. 5c). However, the standard errors had increased relative to 2010, indicating greater within-treatment differences (cf. RED data).
BGD

$10,15851-15877,2013$

Recovery and

invasibility dynamics

after seasonal $50-y r$

climate extremes

F. E. Dreesen et al.

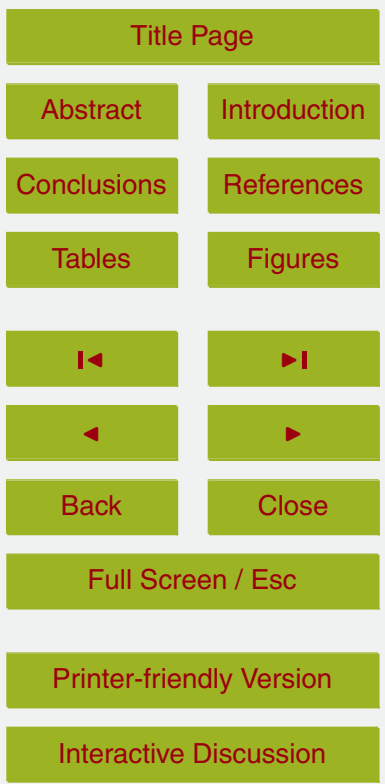




\section{Discussion}

Summer and autumn drought and combined drought and heat extremes caused high mortality and a strong decline in aboveground biomass, which likely diminished carbon sequestration and affect the nutrient balance of these communities as well. Because 5 of local mortality, more available nutrients combined with more space and/or light can indeed explain the increased susceptibility of the communities that had the greatest mortality to invasion of new species one year later (Davis et al., 2000). However, this effect only lasted for one year. Two years after the events had passed, the establishment of new species could no longer be related to the impact the extreme events had caused. Probably, after one year, all open niches were filled again and a new dynamic balance existed in the communities. Also the biomass reductions caused by the extreme events had disappeared after one year, indicating that any potential effects on carbon and/or nutrient cycling could also be transient.

All three originally planted species suffered similar die-back during the extreme events, which was greatest after the combined drought and heat events in summer and autumn. However, while the biomass of Rumex acetosella and Plantago lanceolata largely recovered from the damage by the end of the same year, the Trifolium repens biomass did not. $T$. repens is known to be drought-sensitive due to its shallow root system and inefficient stomatal control, resulting in accelerated leaf wilting and die off (Hart, 1987). In general, T. repens is capable of making osmotic adjustments in the stolons to allow conservation of and regrowth from these organs once water availability increases again (Turner, 1990a, b). Given the poor regrowth, the stress in our treatments may have been too intense to initiate or maintain this adjustment, or to conserve sufficient roots in the surviving plants.

25 The response of the community biomass was clearly dominated by the strong decline of $T$. repens. A single dominant can thus determine the stability or persistence of an entire community (Buckland et al., 1997; Burke and Grime, 1996; Evans et al., 2011; Sasaki and Lauenroth, 2011; Spehn et al., 2002). After the combined extreme in
BGD

10, 15851-15877, 2013

Recovery and

invasibility dynamics

after seasonal 50-yr

climate extremes

F. E. Dreesen et al.

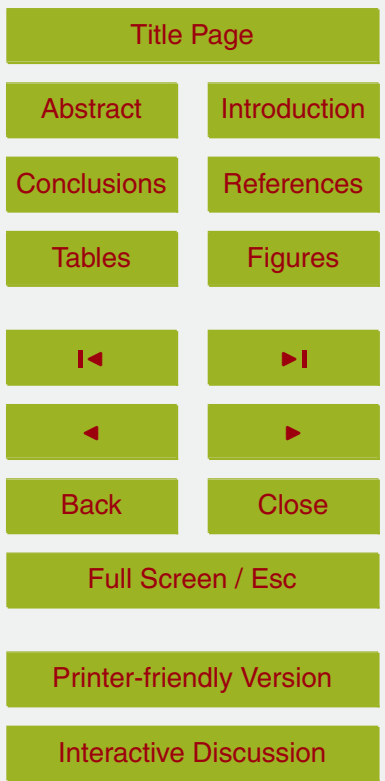


summer, T. repens was no longer the principal species in the community, and species composition shifted to a state dominated by more stress-tolerant species. Such shifts have been observed in other studies as well, where disturbance events disrupted the original equilibrium by favouring tolerant, less competitive species (Buckland et al., 5 1997; Burke and Grime, 1996; Dunnett et al., 1998; Evans et al., 2011; Kreyling et al., 2011; Stampfli and Zeiter, 2004). In the current study, the switch in dominance towards more stress-tolerant species disappeared completely after two years. Nevertheless, in spite of this restored balance between CSR strategies, the dominant species in the community had altered, which can have important implications for the functioning of an ecosystem, since species have different ecophysiological traits that can influence the carbon, nitrogen, or other cycles of ecosystems. Examples of such traits are size, growth rate, root structure, life history (annual versus perennial), tissue chemistry or ability to establish symbiotic relationships belowground, all of which influence resource dynamics within an ecosystem (Jackson et al., 2002; Kardol et al., 2010; Liao et al.,

2008). In the current study, such a change in ecosystem functioning was observed in the community biomass one year after the climate extremes. Although the biomass reductions caused by the extreme events had disappeared by then, the $2010 \mathrm{com}$ munities produced only one third of the biomass in 2009. Probably the decline of the atmospheric nitrogen fixer $T$. repens was at the basis of this productivity loss. St. John et al. (2012) likewise found that the removal of a nitrogen fixing shrub led to a 7-fold reduction in the productivity of the other woody plants present, resulting from reduced inputs of nitrogen. Unexpectedly, T. repens also largely disappeared from the control plots in 2010, inducing similar biomass losses as in the extreme event treatments.

In several invasion studies the identity of the invading species determined their establishment success after a disturbance event (Dunnett et al., 1998; Evans et al., 2011; Buckland et al., 1997; Stampfli and Zeiter, 2004; Kreyling et al., 2008a; Jiménez et al., 2011). The current study does not confirm these findings. The large variation in species biomass that we observed within the same extreme treatment indicates that invasion was purely stochastic. We argue that the invasion was mostly driven by chance and re-
BGD

$10,15851-15877,2013$

Recovery and

invasibility dynamics

after seasonal $50-y r$

climate extremes

F. E. Dreesen et al.

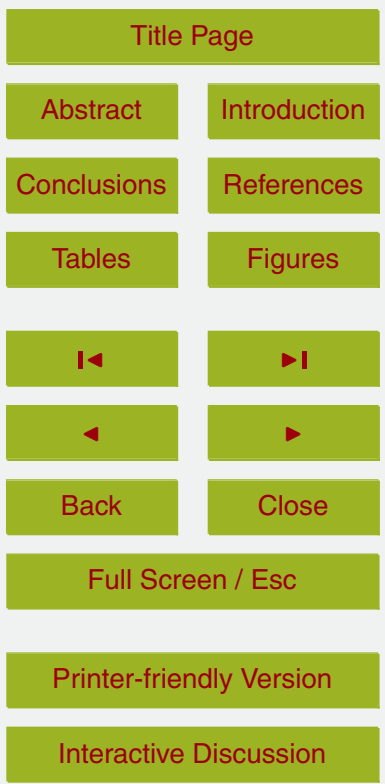


gional propagule abundances, and was thus independent of the traits of the invaders. Several studies have indeed reported that propagule pressure is the main predictor for invasion success (Eckstein et al., 2012; Simberloff, 2009; Thomsen et al., 2006; Von Holle and Simberloff, 2005) and more studies suggest that community assembly is not 5 related to specific species traits, but rather a random process driven by demographic stochastic drift (Herben et al., 2004; Hubbell, 2001). Furthermore, since our plant communities originally consisted of three species, they were probably most representative for early succession. During these early stages of community assemblage, competition is lower and stochastic processes, the soil seed bank or seed dispersal are believed 10 to drive community assembly (Bakker et al., 2005; Kirmer and Mahn, 2001; Del Moral and Lacher, 2005; MacDougall and Turkington, 2006). In later successional and more productive communities, on the other hand, compositional changes are expected to be driven mainly by competition and to follow deterministic rules (MacDougal et al. 2008). It is therefore possible that specific species assemblages can still be discovered in dif15 ferent extreme event treatments but only after a longer stabilizing period than the two years of our experiment.

\section{Conclusions}

In conclusion, drought extremes (both with and without the co-occurrence of extreme heat), strongly affected aboveground productivity and mortality but the impact differed

between species. The species composition in terms of community competitiveness and stress-tolerance was disrupted particularly by the combined heat and drought extreme in summer, though only temporarily. By inducing mortality, the extreme events accelerated the invasion of new species, but differences between the treatments levelled out fairly quickly. After two years without major disturbances, trends in newly estabnity biomass between the treatments had disappeared already after one year. Invasibility and community productivity were thus fairly robust against the imposed extreme

BGD

$10,15851-15877,2013$

Recovery and

invasibility dynamics

after seasonal 50-yr

climate extremes

F. E. Dreesen et al.

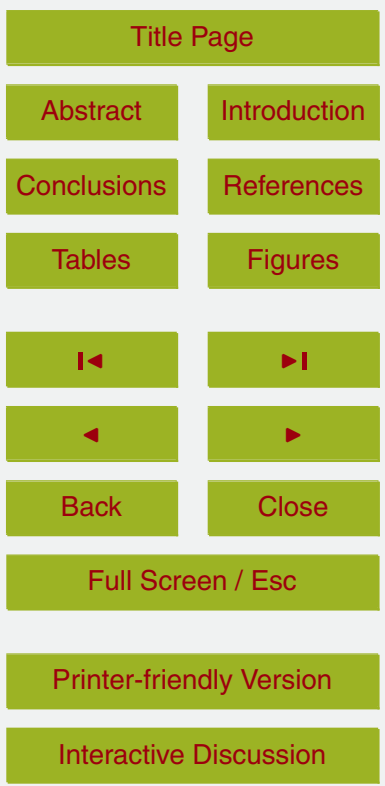


events. In the two years following the climate extremes, the composition of the plant communities developed at random and independent of the type of extreme event they were subjected to.

\section{Supplementary material related to this article is available online at 5 http://www.biogeosciences-discuss.net/10/15851/2013/ bgd-10-15851-2013-supplement.pdf.}

Acknowledgements. H .J. De Boeck is a post-doctoral research associate of the Fund for Scientific Research-Flanders. We thank Marc Wellens and Fred Kockelbergh for technical assistance and Wout Opdekamp for his help in identifying the plant seedlings.

\section{References}

Arnone, J. A., Verburg, P. S. J., Johnson, D. W., Larsen, J. D., Jasoni, R. L., Lucchesi, A. J., Batts, C. M., von Nagy, C., Coulombe, W. G., Schorran, D. E., Buck, P. E., Braswell, B. H., Coleman, J. S., Sherry, R. A., Wallace, L. L., Luo, Y. Q., and Schimel, D. S.: Prolonged suppression of ecosystem carbon dioxide uptake after an anomalously warm year, Nature, 455, 383-386, 2008.

Bakker, C., de Graaf, H. F., Ernst, W. H. O., and van Bodegom, P. M.: Does the seed bank contribute to the restoration of species-rich vegetation in wet dune slacks?, Appl. Veg. Sci., 8, 39-48, 2005.

Belote, R. T., Jones, R. H., Hood, S. M., and Wender, B. W.: Diversity-invasibility across an experimental disturbance gradient in Appalachian forests, Ecology, 89, 183-192, 2008.

Bréda, N., Huc, R., Granier, A., and Dreyer, E.: Temperate forest trees and stands under severe drought: a review of ecophysiological responses, adaptation processes and long-term consequences, Ann. For. Sci., 63, 625-644, 2006.

Breshears, D. D., Cobb, N. S., Rich, P. M., Price, K. P., Allen, C. D., Balice, R. G., Romme, W. 25 H., Kastens, J. H., Floyd, M. L., Belnap, J., Anderson, J. J., Myers, O. B., and Meyer, C. W.:
Recovery and

invasibility dynamics

after seasonal $50-y r$

climate extremes

F. E. Dreesen et al.

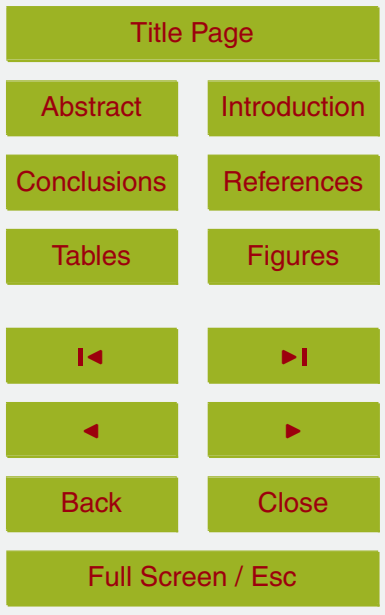

Printer-friendly Version

Interactive Discussion 
Regional vegetation die-off in response to global-change-type drought, P. Natl. Acad. Sci. USA, 102, 15144-15148, 2005.

Buckland, S. M., Grime, J. P., Hodgson, J. G., and Thompson, K.: A comparison of plant responses to the extreme drought of 1995 in northern England, J. Ecol., 85, 875-882, 1997.

5 Burke, M. J. W. and Grime, J. P.: An experimental study of plant community invasibility, Ecology, 77, 776-790, 1996.

Ciais, P., Reichstein, M., Viovy, N., Granier, A., Ogee, J., Allard, V., Aubinet, M., Buchmann, N., Bernhofer, C., Carrara, A., Chevallier, F., De Noblet, N., Friend, A. D., Friedlingstein, P., Grunwald, T., Heinesch, B., Keronen, P., Knohl, A., Krinner, G., Loustau, D., Manca, G., Matteucci, G., Miglietta, F., Ourcival, J. M., Papale, D., Pilegaard, K., Rambal, S., Seufert, G., Soussana, J. F., Sanz, M. J., Schulze, E. D., Vesala, T., and Valentini, R.: Europe-wide reduction in primary productivity caused by the heat and drought in 2003 , Nature, 437, 529533, 2005.

Clark, G. F. and Johnston, E. L.: Temporal change in the diversity-invasibility relationship in the presence of a disturbance regime, Ecol. Lett., 14, 52-57, 2011.

Davis, M. A. and Pelsor, M.: Experimental support for a resource-based mechanistic model of invasibility, Ecol. Lett., 4, 421-428, 2001.

Davis, M. A., Grime, J. P., and Thompson, K.: Fluctuating resources in plant communities: a general theory of invasibility, J. Ecol., 88, 528-534, 2000.

Davis, M. A., Thompson, K., and Grime, J. P.: Invasibility: the local mechanism driving community assembly and species diversity, Ecography, 28, 696-704, 2005.

De Boeck, H. J., Dreesen, F. E., Janssens, I. A., and Nijs, I.: Whole-system responses of experimental plant communities to climate extremes imposed in different seasons, New Phytol., 189, 806-817, 2011.

Del Moral, R. and Lacher, I. L.: Vegetation patterns 25 years after the eruption of Mount St. Helens Washington, USA, Am. J. Bot., 92, 1948-1956, 2005.

Dukes, J. S.: Biodiversity and invasibility in grassland microcosms, Oecologia, 126, 563-568, 2001.

Dunnett, N. P., Willis, A. J., Hunt, R., and Grime, J. P.: A 38-year study of relations between weather and vegetation dynamics in road verges near Bibury, Gloucestershire, J. Ecol., 86, 610-623, 1998.

BGD

$10,15851-15877,2013$

Recovery and

invasibility dynamics

after seasonal $50-y r$

climate extremes

F. E. Dreesen et al.

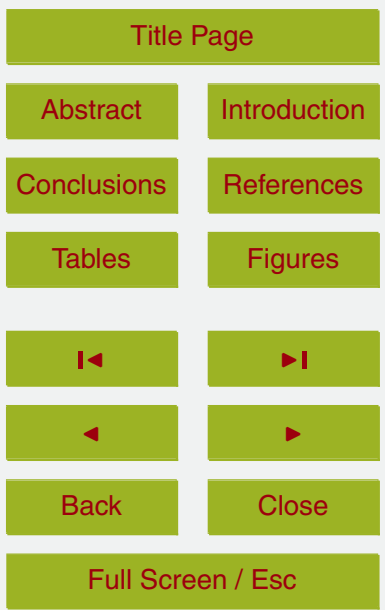

Printer-friendly Version

Interactive Discussion 
Eckstein, R. L., Ruch, D., Otte, A., and Donath, T. W.: Invasibility of a nutrient-poor pasture through resident and non-resident herbs is controlled by litter, gap size and propagule pressure, PLoS One, 7, e41887, doi:10.1371/journal.pone.0041887, 2012.

Evans, S. E., Byrne, K. M., Lauenroth, W. K., and Burke, I. C.: Defining the limit to resistance 5 in a drought-tolerant grassland: long-term severe drought significantly reduces the dominant species and increases ruderals, J. Ecol., 99, 1500-1507, 2011.

Fargione, J., Brown, C. S., and Tilman, D.: Community assembly and invasion: An experimental test of neutral versus niche processes, P. Natl. Acad. Sci. USA, 100, 8916-8920, 2003.

Frankow-Lindberg, B. E.: Grassland plant species diversity decreases invasion by increasing resource use, Oecologia, 169, 793-802, 2012.

Grime, J. P., Hodgson, J. G., and Hunt, R.: Comparative plant ecology, Unwin Hyman, London, 1988.

Hanson, P. J. and Weltzin, J. F.: Drought disturbance from climate change: response of United States forests, Sci. Total Environ., 262, 205-220, 2000.

Hart, A. L.: Physiology. In White Clover. Eds. MJ Baker and WM Williams, 125-151, CAB International, Wellingford, 1987.

Herben, T., Mandak, B., Bimova, K., and Munzbergova, Z.: Invasibility and species richness of a community: A neutral model and a survey of published data, Ecology, 85, 3223-3233, 2004.

Hubbell, S. P.: The unified neutral theory of biodiversity and biogeography, Princeton University Press, Princeton and Oxford, 369 pp., 2001.

IPCC: Managing the Risks of Extreme Events and Disasters to Advance Climate Change Adaptation. A Special Report of Working Groups I and II of the Intergovernmental Panel on Climate Change in, edited by: Field, C. B., Barros, V., Stocker, T. F., Qin, D., Dokken, D. J., Ebi, K. L., Mastrandrea, M. D., Mach, K. J., Plattner, G.-K., Allen, S. K., Tignor, M., and Midgley, P. M., Cambridge University Press, Cambridge, UK and New York, USA, 582, 2012.

Jackson, R. B., Banner, J. L., Jobbagy, E. G., Pockman, W. T., and Wall, D. H.: Ecosystem carbon loss with woody plant invasion of grasslands, Nature, 418, 623-626, 2002.

Jiménez, M. A., Jaksic, F. M., Armesto, J. J., Gaxiola, A., Meserve, P. L., Kelt, D. A., and Gutiér30 rez, J. R.: Extreme climatic events change the dynamics and invasibility of semi-arid annual plant communities, Ecol. Lett., 14, 1227-1235, 2011.
BGD

10, 15851-15877, 2013

Recovery and

invasibility dynamics

after seasonal 50-yr

climate extremes

F. E. Dreesen et al.

Title Page

Abstract

Introduction

Conclusions

Tables

References

Figures

14

4

Back

Full Screen / Esc

Printer-friendly Version

Interactive Discussion 
Kardol, P., Campany, C. E., Souza, L., Norby, R. J., Weltzin, J. F., and Classen, A. T.: Climate change effects on plant biomass alter dominance patterns and community evenness in an experimental old-field ecosystem, Global Change Biol., 16, 2676-2687, 2010.

Kirmer, A. and Mahn, E. G.: Spontaneous and initiated succession on unvegetated slopes in the abandoned lignite-mining area of Goitsche, Germany, Appl. Veg. Sci., 4, 19-27, 2001.

Kreyling, J., Beierkuhnlein, C., Ellis, L., and Jentsch, A.: Invasibility of grassland and heath communities exposed to extreme weather events - additive effects of diversity resistance and fluctuating physical environment, Oikos, 117, 1542-1554, 2008a.

Kreyling, J., Wenigmann, M., Beierkuhnlein, C., and Jentsch, A.: Effects of extreme weather events on plant productivity and tissue die-back are modified by community composition, Ecosystems, 11, 752-763, 2008b.

Kreyling, J., Jentsch, A., and Beierkuhnlein, C.: Stochastic trajectories of succession initiated by extreme climatic events, Ecol. Lett., 14, 758-764, 2011.

Liao, C. Z., Peng, R. H., Luo, Y. Q., Zhou, X. H., Wu, X. W., Fang, C. M., Chen, J. K., and Li,

15 B.: Altered ecosystem carbon and nitrogen cycles by plant invasion: a meta-analysis, New Phytol., 177, 706-714, 2008.

MacDougall, A. S. and Turkington, R.: Dispersal, competition, and shifting patterns of diversity in a degraded oak savanna, Ecology, 87, 1831-1843, 2006.

MacDougall, A. S., Wilson, S. D., and Bakker, J. D.: Climatic variability alters the outcome of long-term community assembly, J. Ecol., 96, 346-354, 2008.

Naeem, S., Knops, J. M. H., Tilman, D., Howe, K. M., Kennedy, T., and Gale, S.: Plant diversity increases resistance to invasion in the absence of covarying extrinsic factors, Oikos, 91, 97108, 2000.

Peñuelas, J., Prieto, P., Beier, C., Cesaraccio, C., de Angelis, P., de Dato, G., Emmett, B. A., 25 Estiarte, M., Garadnai, J., Gorissen, A., Lang, E. K., Kroel-Dulay, G., Llorens, L., Pellizzaro, G., Riis-Nielsen, T., Schmidt, I. K., Sirca, C., Sowerby, A., Spano, D., and Tietema, A.: Response of plant species richness and primary productivity in shrublands along a north-south gradient in Europe to seven years of experimental warming and drought: reductions in primary productivity in the heat and drought year of 2003, Global Change Biol., 13, 2563-2581, $30 \quad 2007$.

Reichstein, M., Bahn, M., Ciais, P., Frank, D., Mahecha, M. D., Seneviratne, S. I., Zscheischler, J., Beer, C., Buchmann, N., Frank, D. C., Papale, D., Rammig, A., Smith, P., Thonicke, K., van
BGD

$10,15851-15877,2013$

Recovery and

invasibility dynamics

after seasonal 50-yr

climate extremes

F. E. Dreesen et al.

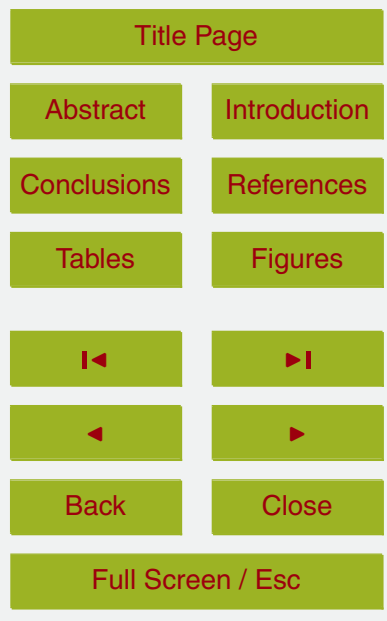

Printer-friendly Version

Interactive Discussion 
der Velde, M., Vicca, S., Walz, A., and Wattenbach, M.: Climate extremes and the carbon cycle, Nature, 500, 287-295, 2013.

Renne, I. J., Tracy, B. F., and Colonna, I. A.: Shifts in grassland invasibility: Effects of soil resources, disturbance, composition, and invader size, Ecology, 87, 2264-2277, 2006.

5 Sasaki, T. and Lauenroth, W. K.: Dominant species, rather than diversity, regulates temporal stability of plant communities, Oecologia, 166, 761-768, 2011.

Shea, K. and Chesson, P.: Community ecology theory as a framework for biological invasions, Trends Ecol. Evol., 17, 170-176, 2002.

Simberloff, D.: The role of propagule pressure in biological invasions, in: Annu. Rev. Ecol. Evol. Syst., Annual Review of Ecology Evolution and Systematics, Annual Reviews, Palo Alto, 81102, 2009.

Spehn, E. M., Scherer-Lorenzen, M., Schmid, B., Hector, A., Caldeira, M. C., Dimitrakopoulos, P. G., Finn, J. A., Jumpponen, A., O'Donnovan, G., Pereira, J. S., Schulze, E. D., Troumbis, A. Y., and Korner, C.: The role of legumes as a component of biodiversity in a cross-European study of grassland biomass nitrogen, Oikos, 98, 205-218, 2002.

St. John, M. G., Bellingham, P. J., Walker, L. R., Orwin, K. H., Bonner, K. I., Dickie, I. A., Morse, C. W., Yeates, G. W., and Wardle, D. A.: Loss of a dominant nitrogen-fixing shrub in primary succession: consequences for plant and below-ground communities, J. Ecol., 100, 10741084, 2012.

Stampfli, A. and Zeiter, M.: Plant regeneration directs changes in grassland composition after extreme drought: a 13-year study in southern Switzerland, J. Ecol., 92, 568-576, 2004.

Thomsen, M. A., D'Antonio, C. M., Suttle, K. B., and Sousa, W. P.: Ecological resistance, seed density and their interactions determine patterns of invasion in a California coastal grassland, Ecol. Lett., 9, 160-170, 2006.

Tilman D.: Niche tradeoffs, neutrality, and community structure: A stochastic theory of resource competition, invasion, and community assembly, P. Natl. Acad. Sci. USA, 101, 10854-10861, 2004.

Turner, L. B.: Water relations of white clover (Trifolium repens): Water potential gradients and plant morphology, Ann. Bot. 65, 285-290, 1990a.

30 Turner, L. B.: The extent and pattern of osmotic potential adjustment in white clover (Trifolium repens L.) during the development of water stress, Ann. Bot. 66, 721-727, 1990b.

van Ruijven, J., De Deyn, G. B., and Berendse, F.: Diversity reduces invasibility in experimental plant communities: the role of plant species, Ecol. Lett., 6, 910-918, 2003.
BGD

$10,15851-15877,2013$

Recovery and

invasibility dynamics

after seasonal 50-yr

climate extremes

F. E. Dreesen et al.

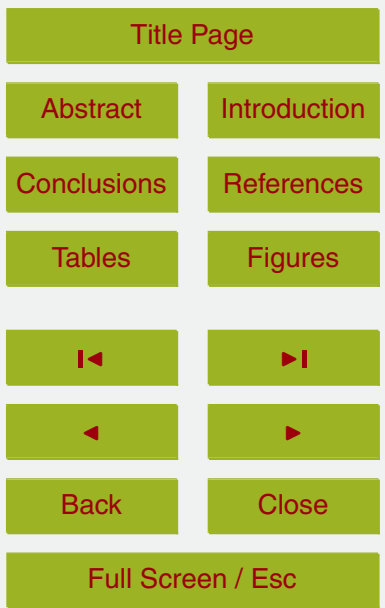

Printer-friendly Version

Interactive Discussion 
Von Holle, B. and Simberloff, D.: Ecological resistance to biological invasion overwhelmed by propagule pressure, Ecology, 86, 3212-3218, 2005.

Wolkovich, E. M., Lipson, D. A., Virginia, R. A., Cottingham, K. L., and Bolger, D. T.: Grass invasion causes rapid increases in ecosystem carbon and nitrogen storage in a semiarid shrubland, Global Change Biol., 16, 1351-1365, 2010.

Recovery and

invasibility dynamics

after seasonal 50-yr

climate extremes

F. E. Dreesen et al.

Title Page

Abstract

Introduction

Conclusions

References

Tables

Figures

14

$\rightarrow 1$

4

Back

Close

Full Screen / Esc

Printer-friendly Version

Interactive Discussion 
Table 1. Mean and standard errors of the Relative Euclidean Distance within replicates of one treatment and between treatments and controls in 2010 and 2011. Bold numbers indicate significant differences from the control. $\mathrm{C}=$ control, $\mathrm{D}=$ drought extreme, $\mathrm{H}=$ heat extreme, $\mathrm{DH}=$ drought + heat extreme.

\begin{tabular}{|c|c|c|c|c|c|c|c|c|c|}
\hline & & \multicolumn{4}{|c|}{2010} & \multicolumn{4}{|c|}{2011} \\
\hline & & \multicolumn{2}{|c|}{ within } & \multicolumn{2}{|c|}{ vs C } & \multicolumn{2}{|c|}{ within } & \multicolumn{2}{|c|}{ vs $\mathrm{C}$} \\
\hline & & mean & se & mean & se & mean & se & mean & se \\
\hline & C & 0.195 & 0.019 & & & 0.254 & 0.014 & & \\
\hline \multirow[t]{3}{*}{ Spring } & D & 0.200 & 0.030 & 0.188 & 0.011 & 0.304 & 0.043 & 0.295 & 0.011 \\
\hline & $\mathrm{H}$ & 0.185 & 0.029 & 0.180 & 0.011 & 0.236 & 0.015 & 0.244 & 0.007 \\
\hline & $\mathrm{DH}$ & 0.171 & 0.017 & 0.180 & 0.009 & 0.223 & 0.022 & 0.259 & 0.009 \\
\hline \multirow[t]{3}{*}{ Summer } & D & 0.169 & 0.020 & 0.181 & 0.010 & 0.158 & 0.017 & 0.255 & 0.009 \\
\hline & $\mathrm{H}$ & 0.165 & 0.023 & 0.190 & 0.012 & 0.212 & 0.033 & 0.264 & 0.010 \\
\hline & $\mathrm{DH}$ & 0.202 & 0.035 & 0.244 & 0.008 & 0.261 & 0.027 & 0.279 & 0.009 \\
\hline \multirow[t]{3}{*}{ Autumn } & D & 0.151 & 0.016 & 0.199 & 0.011 & 0.184 & 0.019 & 0.230 & 0.009 \\
\hline & $\mathrm{H}$ & 0.119 & 0.017 & 0.191 & 0.012 & 0.174 & 0.015 & 0.226 & 0.008 \\
\hline & $\mathrm{DH}$ & 0.201 & 0.023 & 0.181 & 0.010 & 0.264 & 0.025 & 0.271 & 0.010 \\
\hline
\end{tabular}

Recovery and invasibility dynamics after seasonal 50-yr climate extremes

F. E. Dreesen et al.

Title Page

Abstract Introduction

Conclusions References

Tables Figures

14 $\rightarrow 1$

4

Back

Close

Full Screen / Esc

Printer-friendly Version

Interactive Discussion 


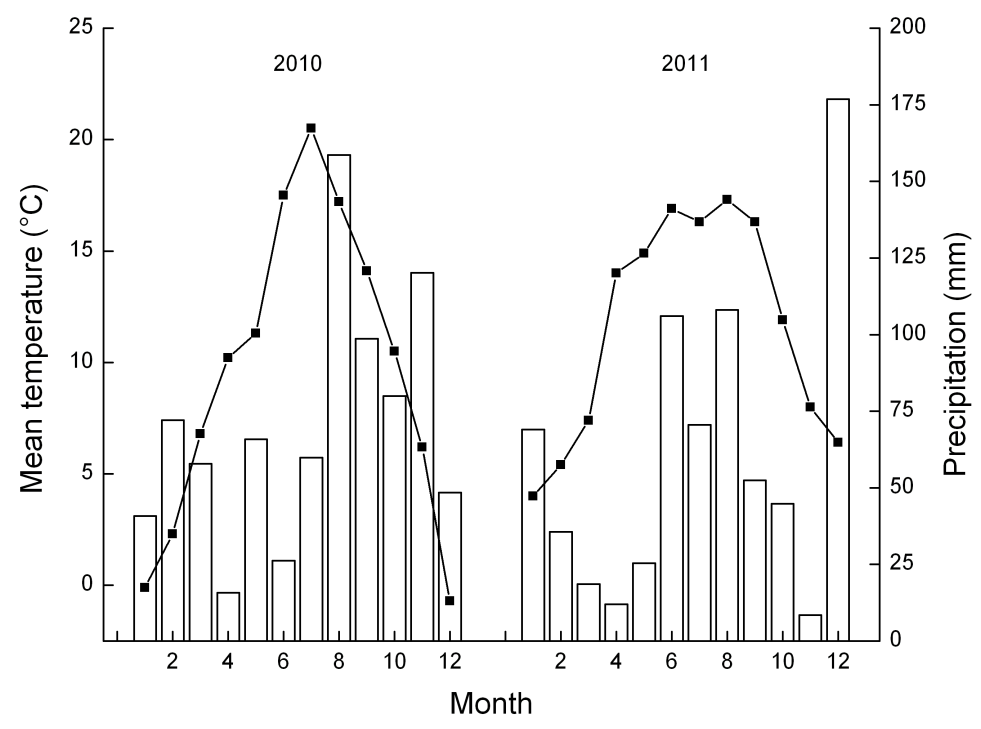

Fig. 1. Overview of environmental conditions during the recovery years 2010 and 2011: mean monthly temperature (black squares) and monthly precipitation (white bars). Data from weather station Lint.
BGD

$10,15851-15877,2013$

Recovery and invasibility dynamics after seasonal $50-\mathrm{yr}$ climate extremes

F. E. Dreesen et al.

\section{Title Page}

\section{Abstract}

Introduction

Conclusions

References

Tables

Figures

14

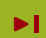

4

Back

Close

Full Screen / Esc

Printer-friendly Version

Interactive Discussion 

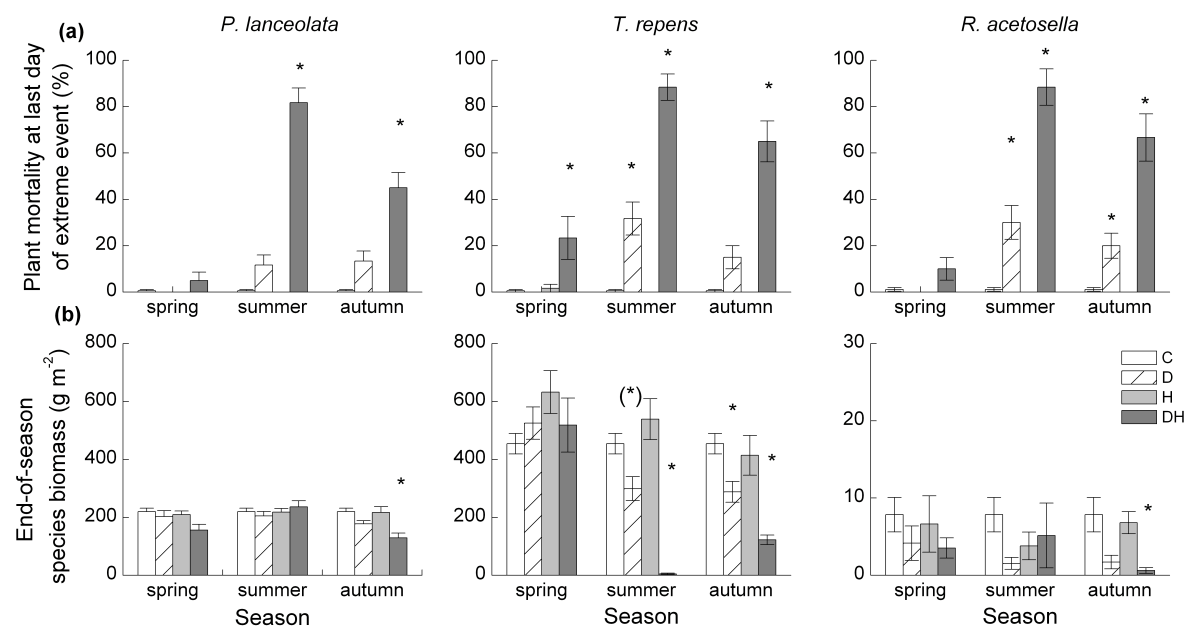

$10,15851-15877,2013$

\section{Recovery and \\ invasibility dynamics \\ after seasonal $50-\mathrm{yr}$ \\ climate extremes \\ F. E. Dreesen et al.}

Fig. 2. (a) Plant mortality at the end of the extreme events in 2009 for the three species and the three seasons (mortality measured at DOY 133, 212 and 282 for the spring, summer and autumn extremes, respectively), (b) biomass at the end of the growing season (DOY 299303) for the three species and the three seasons. Asterisks above bars indicate significant differences from the control $(P<0.05)$. The asterisk between brackets indicates a borderline significant difference $(P<0.06) . \mathrm{C}=$ control (white bars), $\mathrm{D}=$ drought extreme (hatched bars), $\mathrm{H}=$ heat extreme (light grey bars), $\mathrm{DH}=$ drought + heat extreme (dark grey bars).

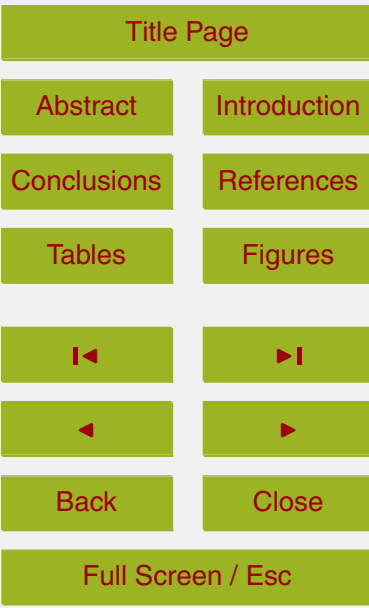

Printer-friendly Version

Interactive Discussion 

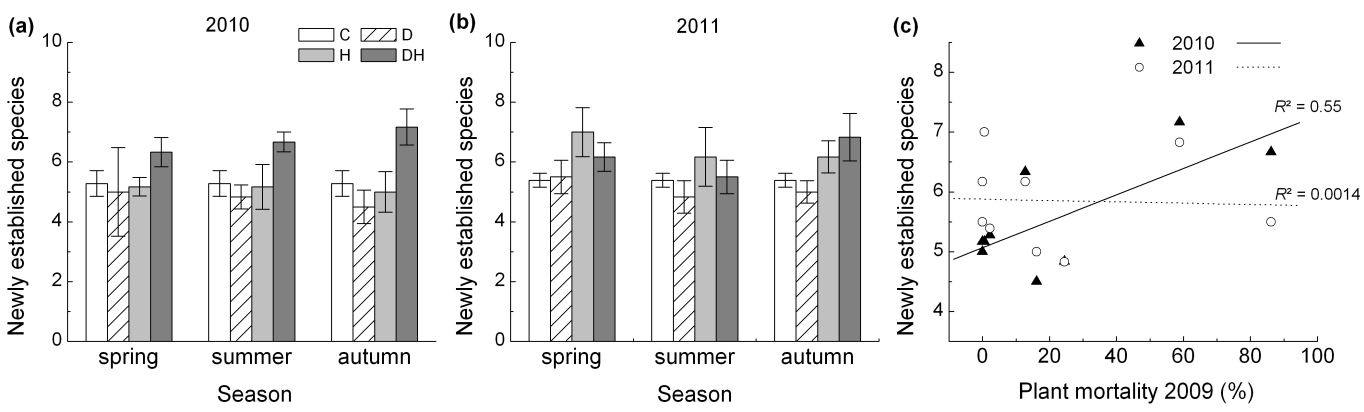

\section{BGD}

10, 15851-15877, 2013

Recovery and

invasibility dynamics

after seasonal $50-\mathrm{yr}$

climate extremes

F. E. Dreesen et al.

\section{Title Page}

\section{Abstract}

Introduction

Conclusions

References

Fig. 3. Number of newly established species (compared to 2009) in (a) 2010 and (b) 2011, and (c) correlation between plant mortality in 2009 and number of newly established species in 2010 (solid line) and 2011 (dotted line). $\mathrm{C}=$ control (white bars), $\mathrm{D}=$ drought extreme (hatched bars), $\mathrm{H}=$ heat extreme (light grey bars), $\mathrm{DH}=$ drought + heat extreme (dark grey bars).

Tables

Figures

14

Back

Close

Full Screen / Esc

Printer-friendly Version

Interactive Discussion 

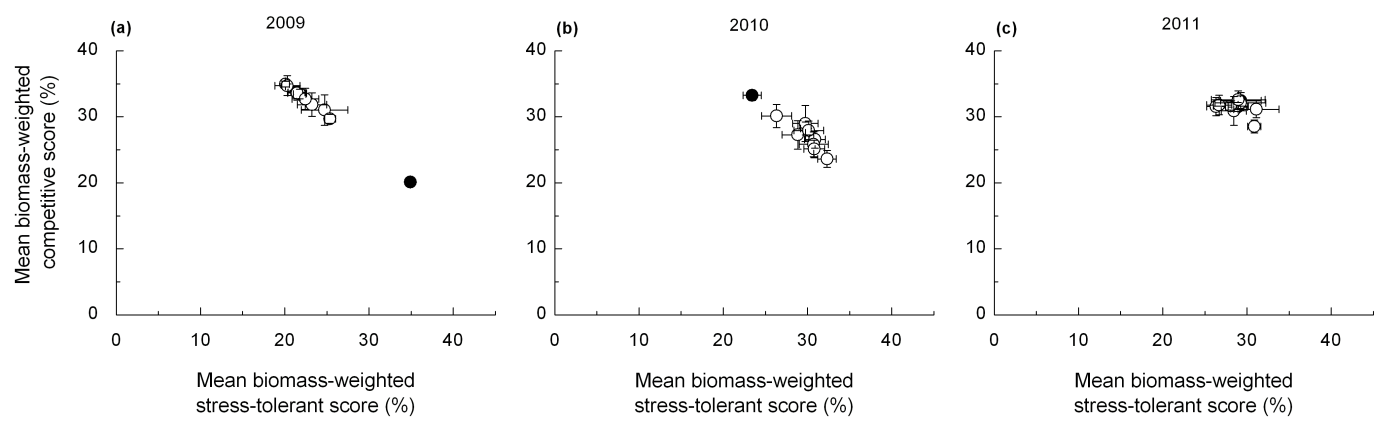

Fig. 4. Mean biomass-weighted competitive score versus the mean biomass-weighted stresstolerant score per treatment in (a) 2009, (b) 2010 and (c) 2011. The black circle represents the summer DH treatment.

\section{BGD}

10, 15851-15877, 2013

Recovery and

invasibility dynamics

after seasonal 50-yr

climate extremes

F. E. Dreesen et al.

Title Page

Abstract

Introduction

Conclusions

References

Tables

Figures

14

\section{$>$ I}

4

Back

Close

Full Screen / Esc

Printer-friendly Version

Interactive Discussion 

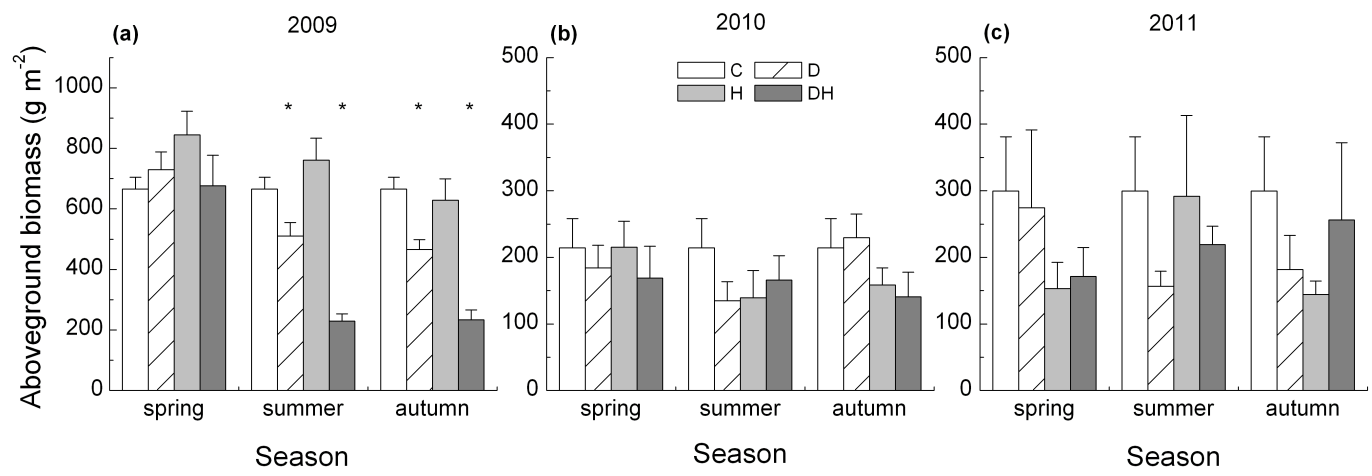

Fig. 5. Aboveground community biomass of the different treatments in (a) 2009, (b) 2010, and (c) 2011. $\mathrm{C}=$ control (white bars), $\mathrm{D}=$ drought extreme (hatched bars), $\mathrm{H}=$ heat extreme (light grey bars), $\mathrm{DH}=$ drought + heat extreme (dark grey bars). Asterisks above bars indicate significant differences from the control.

Recovery and invasibility dynamics after seasonal 50-yr climate extremes

F. E. Dreesen et al.

\section{Title Page}

\section{Abstract}

Introduction

Conclusions

References

Tables

Figures

14

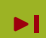

Back

Close

\section{Full Screen / Esc}

Printer-friendly Version

Interactive Discussion 